\title{
Effects of substrate preference on growth and survival of blue tiger crayfish (Cherax albertisii)
}

\section{Substrat seçiminin mavi kaplan kerevitlerinde (Cherax albertisii) büyüme ve yaşama oranı üzerine etkileri}

\section{Onur Karadal* • Gürel Türkmen}

Ege University, Faculty of Fisheries, Department of Aquaculture, 35100, Bornova, Izmir, Turkey

*Corresponding author: onurkaradal@gmail.com

How to cite this paper:

Karadal, O., Türkmen, G., 2014. Effects of substrate preference on growth and survival of blue tiger crayfish (Cherax albertisii). Ege J Fish Aqua Sci 31(1): 1-4. doi: 10.12714/egejfas.2014.31.1.01

\begin{abstract}
Özet: Bu çalışmada, farklı türde substratların mavi kaplan kerevitlerinde (Cherax albertisii) büyüme, yaşama oranı ve substrat seçimi üzerine etkileri araştırımıştır. 6 farklı substrat (boş cam, sinek teli, bazalt, kalsit, çakıl, kum) 18 adet akvaryumun zeminine yerleştirilmiştir. Çalışma 2 farklı deney ortamında sürdürülmüştür. İlk deneyde her bir akvaryuma ortalama $1 \mathrm{~g}$ ağırlığında 10 adet birey konulmuştur. İkinci deneyde, substrat tercihi için tabanından 6 bölüme ayrımış ve her bir bölümde aynı substratların bulunduğu altıgen bir akvaryum kullanılmıştır. İlk deneyden 1 aylık 10 adet kerevit bireysel olarak altıgen tanka yerleştirilmiş ve hareketlerini gözlemlemek için 24 saat boyunca her bölümde geçirdikleri süreler kaydedilmiştir. İlk deneyin sonucu olarak, 120 günün sonunda çakıl substratındaki bireylerin ağılıklarında istatistiksel farklılık saptanmıştır $(P<0,01)$. İkinci deney sonunda çakıl substratında geçirilen sürede belirgin bir farkılık gözlenmiştir $(P<0,01)$. Bu deneyler jüvenil mavi kaplan kerevitleri için çakıl substratının kullanılabilir olduğunu göstermiştir. Çalışma sonuçları, çakılın $C$. albertisii türü için doğal substratına yakın olmasından dolayı doğal substratın bu tür açısından oldukça önemli olduğunu göstermiştir.
\end{abstract}

Anahtar kelimeler: Kerevit, Substrat, Büyüme, Yaşama Oranı, Cherax albertisii.

Abstract: This study investigated the effects of different type of substrates on the growth, survival and substrate preference on juvenile blue tiger crayfish (Cherax albertisii). Six different substrates (bare glass, plastic mesh, basalt, calcite, pebbles, sand) have established in the bottom of 18 aquariums. The study was carried out in two different experimental areas. In the first set of experiments, ten (average $1 \mathrm{~g}$ of body weight) juveniles were placed in each aquariums. In the second experiment, a hexagonal glass aquarium were used and divided into six sections each containing one of the same substrates were used for substrate preference. Ten juveniles from the first experiment were individually placed into the aquarium and each of them were recorded at convenient intervals for 24 hours for observing their behaviours. Spending time in each section was recorded. As a result of the first experiment, it was found that weight gain of crayfish was significantly higher on group of pebbles in comparison with the other substrates after 120 days $(P<0.01)$. At the end of the second experiment we observed that pebbles was the most preferred when compared the other substrates $(P<0.01)$. The present experiments suggest that the pebbles can be used as a substrate for juvenile blue tiger crayfish. These results showed that the natural habitat is quite important for this species because of pebbles are close to natural substrate of $C$. albertisii.

Keywords: Crayfish, Substrate, Growth, Survival, Cherax albertisii.

\section{INTRODUCTION}

Aquarium keeping is amongst the most popular of hobbies with millions of enthusiasts worldwide. Today, ornamental fish comprise a very large and diverse global industry, with trading in over 4,500 species of freshwater fish, 1,450 species of marine fish, and over 650 species of corals and other marine invertebrates (Miller-Morgan, 2010). Not only finfishes, but also a wide range of invertebrates are found good to be kept in captivity. In fact, new species are now being introduced to hobbyists at a remarkable pace, especially freshwater decapod crustaceans such as shrimps, crayfish and crabs. Among these decapods, crayfish were become more popular in the last decade. The worldwide success of the freshwater crayfish aquaculture industry during recent decades has been based on the selection of species with adequate characteristics for both culturing and commercial purposes. There are more than 100 species of Australian crayfish, but only few species of the genus Cherax are currently being farmed due to their high commercial potential and traded ornamental purposes (Viau and Rodríguez, 2010). There are many different reasons for maintaining crayfish in the home aquarium. Especially, more than exotic and colourful crayfish species are preferred for ornamental purposes, such as Cherax quadricarinatus, Cherax destructor, Cherax tenuimanus, Astacopsis gouldi, Cambarellus patzcuarensis, Cambarellus shufeldtii, Procambarus clarkii and Procambarus alleni (Wingerter, 2011). 
The ornamental aquarium trade in Turkey started to develop as an industry after 1980s. After this period, a large number and type of aquarium fish have been started to import (Türkmen and Alpbaz, 2001). Although keeping decapods in freshwater aquariums is a new popularity in Turkey, many shrimp, crayfish and crab species commonly seen for sale in virtual pet stores. There are 9 exhibiting freshwater crayfish species including Cherax albertisii in ornamental aquarium trade in Turkey (Türkmen and Karadal, 2012a).

Substrate type has been recognized as important in freshwater communities. Crayfish live in sandy and muddy benthic areas. Unlike most crustacean decapods, crayfish spend their entire life on a substrate on the benthic fauna. In aquarium systems, the burrowing behaviours of some species contribute to the turning of the aquarium substrate and the cycling of detritus. Crayfish are typically considered keystone species to the biological communities because of their feeding and burrowing behaviours (Wingerter, 2011). Therefore substrate is a part of their life for crayfish in stages of their entire life. Although there are few studies releated to feeding, growth, survival, phenotype and genotype characteristics on C. albertisii (Kurniasih, 2008; Kusmini, 2009), no study about substrate preference on this species. In the present study, effects of six different substrates on growth and survival of juvenile blue tiger crayfish were investigated and also their substrate preference was observed, as well.

\section{MATERIALS AND METHOD}

\section{Evaluation of the substrate type}

Juveniles (1 $\mathrm{g}$ of body weight) of Cherax albertisii were used in the study. Crayfish were provided from a commercial facility (Nemo Aquarium, Dikili, İmir). All the experiments were carried out in glass aquariums $\left(1,400 \mathrm{~cm}^{2}\right.$ of bottom surface) filled with $8 \mathrm{~L}$ of dechlorinated tap water continuously aerated. Temperature was maintained at $25 \pm 1{ }^{\circ} \mathrm{C}$, and photoperiod was held at 14:10 (light:dark). The water in all aquariums was changed twice a week. Every day, all animals were fed ad libitum with commercial feed (Ecobio ${ }^{\circledR} 2 \mathrm{~mm}$ granule, $44 \%$ of protein) twice a day. Dissolved oxygen (WTW-Oxi 315, precision of $\pm 0.5 \mathrm{mg} / \mathrm{L}$ ), $\mathrm{pH}$ (Sartorius PT-10, precision of $\pm 0.01 \mathrm{~g}$ ), ammonia (HANNA C205, precision of $\pm 0.04 \mathrm{mg} / \mathrm{L}$ ), total hardness (measured with Aquamerck ${ }^{\circledR}$ kit, $^{2}$ 114652 total hardness test) and alkalinity (measured with Aquamerck $^{\circledR}$ kit, 111109 alkalinity test) were determined in each aquaria at the beginning and at the end of the experiment before changing water and feeding the animals.

Ten juveniles crayfish were placed in each aquarium. Each aquarium contained $3 \mathrm{~cm}$ diameter PVC pipes as a shelter. Six substrates were tested: bare glass (control), plastic mesh (a mesh similar to mosquito netting adhered to the bottom of the aquaria), pebbles, sand, basalt and calcite. Particulated substrates (pebbles, sand, basalt and calcite) were covered the bottom of the aquariums for $0.5 \mathrm{~cm}$ thick. All substrates were repeated in triplicate for a total of six aquariums. At the end of 120 days experiment, the mortality was recorded and dead animals were removed daily from all aquariums. Total length $(T L)$ of the animals was measured to the nearest $0.1 \mathrm{~mm}$ from the tip of the rostrum to the tip of the telson at over the 120-day experimental period. Juveniles were put on filter paper to remove excess water, and weighed to the nearest $0.01 \mathrm{~g}$ with an electronic balance (Sartorius BL610, precision of $\pm 0.01 \mathrm{~g}$ )

\section{Substrate preference}

Hexagonal glass aquarium (60 $\mathrm{cm}$ of length of diagonal) divided into six equal compartments each containing different substrates (substrates which are used in the first experiment) was used for substrate preference experiment. The aquarium was filled with $7 \mathrm{~L}$ of dechlorinated water. Ten juveniles crayfish from the first experiment were individually placed in the center of the hexagonal aquarium and the movement of each individual in the study area covered by the substrates was recorded with a web camera (Piranha ${ }^{\circledR}$ ) by locating directly above the center of the aquarium for $24 \mathrm{~h}$ (Figure 1). Spending time in each section was observed from this a web camera. The experimental area was observed from computer screen because of the fact that it was placed in a closed room for preventing stress factors. Ambient temperature in the room was maintained at $25 \pm 1{ }^{\circ} \mathrm{C}$ and photoperiod was regulated 14:10 (light:dark). During the light phase, a white lamp was located above the aquarium and connected to a timer. During the dark phase, infrared LEDs located around the web camera. Animals were not fed during the experiment.

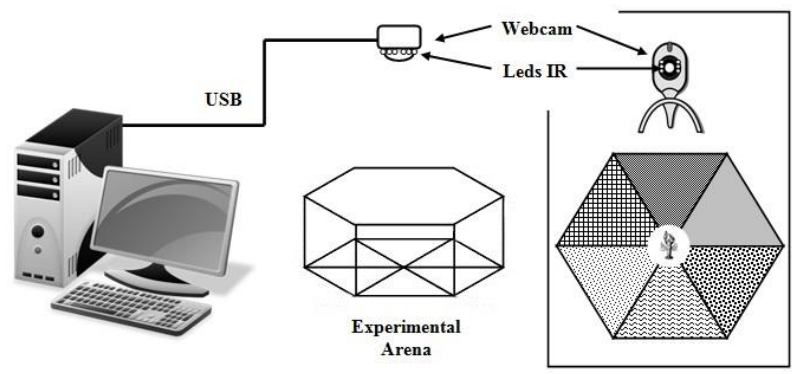

Figure 1. Model of the experimental area used for the substrate preference experiment.

\section{Statistical analysis}

Growth and substrate preference data were analyzed by using a one-way analysis of variance (ANOVA). The homogeneity of variance was verified by a parametric Levene test and the normality was verified by a Kolmogorov-Smirnov test. Statistical differences were examined by StudentNewman-Keuls (SNK) test. Survival data was analyzed with a one-tail Fisher test. All statistical analyses were performed using SPSS 15.0 (SPSS Inc., Chicago, IL, USA) and MS Office Excel was used for creating graphics. All significant tests were at $P<0.01$ level. 


\section{RESULTS}

As a result of the first experiment, it was found that weight gain of crayfish was significantly higher on group of pebbles substrates in comparison with the other substartes $(P<0.01)$. This result indicated that the type of subtrate was an important factor for their growth. According to result of the second experiment, crayfish spent the most time on pebbles substrate. The mean body weight of juveniles crayfish in the calcite, sand, and pebbles were significantly greater $(P<0.01)$ than those in the glass (control) substrate, while the plastic net and basalt caused an intermediate effect. Differences among the mean weights of crayfish are starting to emerge after 80 days (Figure 2). There were no significant differences in total length and survival of juveniles crayfish (Table 1).

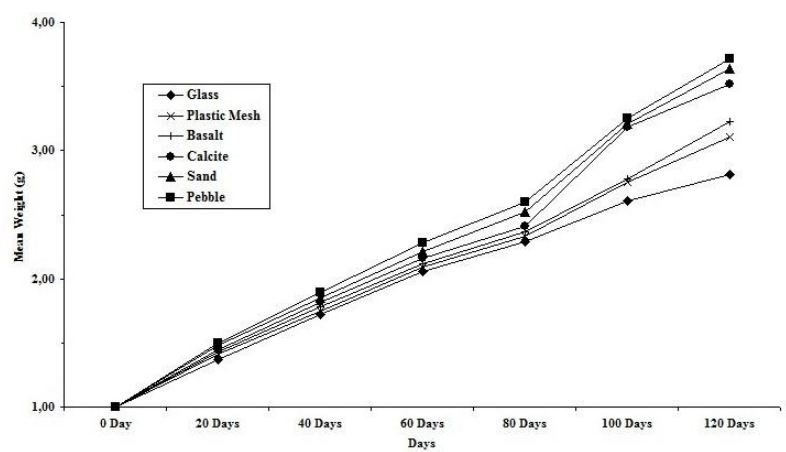

Figure 2. Comparison of weight (g) of crayfish juvenile for 120 days.

Table 1. Mean total length, body weight, and survival ( \pm standard errors) versus substrate type for juveniles after 120 days.

\begin{tabular}{|c|c|c|c|}
\hline Substrates & Total Length $(\mathbf{c m})$ & Body Weight (g) & Survival (\%) \\
\hline Glass & $4.26 \pm 0.34$ & $2.81 \pm 0.21^{\mathrm{a}}$ & $80.0 \pm 0.5$ \\
\hline Plastic Mesh & $4.41 \pm 0.33$ & $3.11 \pm 0.23^{\mathrm{a}, \mathrm{b}}$ & $70.0 \pm 1.0$ \\
\hline Basalt & $4.52 \pm 0.39$ & $3.23 \pm 0.32^{\mathrm{a}, \mathrm{b}}$ & $75.0 \pm 1.0$ \\
\hline Calcite & $4.78 \pm 0.37$ & $3.52 \pm 0.33^{\mathrm{b}}$ & $75.0 \pm 1.0$ \\
\hline Sand & $4.89 \pm 0.22$ & $3.64 \pm 0.25^{\mathrm{b}}$ & $90.0 \pm 0.5$ \\
\hline Pebble & $4.94 \pm 0.25$ & $3.72 \pm 0.30^{\mathrm{b}}$ & $90.0 \pm 0.5$ \\
\hline
\end{tabular}

Different letters $(a, b)$ represent statistically significant differences $(P<0.01)$.

The water quality parameters did not change significantly $(P<0.01)$ among the treatments. The means values of $\mathrm{pH}$ was in the range 7.3-8.0, dissolved oxygen between 5 and $6 \mathrm{mg} / \mathrm{L}$, ammonia values were below of $0.08 \mathrm{mg} / \mathrm{L}$, alkalinity show a range between 85 and $95 \mathrm{mg} / \mathrm{L}$, hardness between 115 and $125 \mathrm{mg} / \mathrm{L}$ and nitrite values registered were in a range 0-0.02 $\mathrm{mg} / \mathrm{L}$.

All the juveniles exhibited a significant $(P<0.01)$ marked preference for pebbles when compared to the other substrates (Figure 3). Sand, basalt, and calcite caused an intermediate effect. Plastic mesh and glass were the lowest time spent substrates in this experiment.

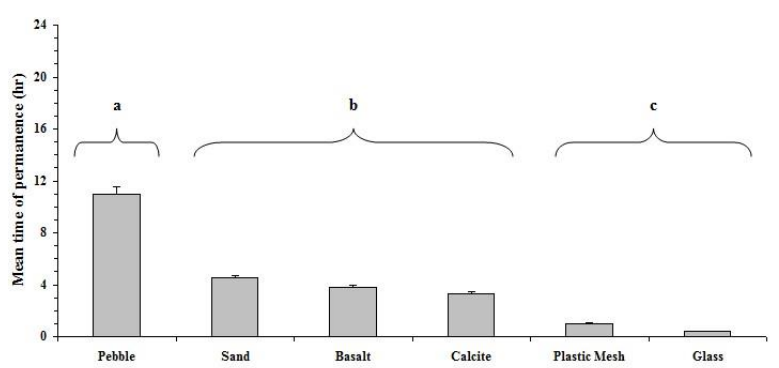

Figure 3. Substrate preference for advanced juveniles expose to experimental substrate arena during 1 day. Different letters $(a, b, c)$ are represent statistically significantly different $(P<0.01)$

\section{DISCUSSIONS}

Previous studies with different substrates have clearly stated that crayfish on the bare glass (control) have the lowest growth and survival rate (Savolainen et al., 2003; Viau and Rodríguez, 2010; Karadal, 2012). These findings are supported by our results. Previous substrate preference studies with different crayfish species, Pacifastacus leniusculus (Savolainen et al., 2003), Cherax quadricarinatus (Viau and Rodríguez, 2010), Cambarellus patzcuarensis (Karadal, 2012), Procambarus clarkii (Türkmen and Karadal, $2012 b$ ), have shown that natural substrates for these species are the most prefered. Herrnkind and Butler (1986) were carried out a study with Caribbean spiny lobster (Panulirus argus) and they reported that natural substrates have important effects. The results of the present study indicated that $C$. albertisii kept in pebbles attained higher body weights. Pebbles are close to natural substrate of $C$. albertisii. These findings are supported by our results, as well.

In nature, C. quadricarinatus and other Australian crayfish are found in either rocky or sandy areas. Juveniles use pebbles as shelter to protect themselves from predation or attacks by conspecifics (Jones and Ruscoe, 2001; Molony and Bird, 2005). Morphologically C. albertisii and C. quadricarinatus have a similarity in body shape and colours (Kusmini, 2009). Also, they prefer the same habitat types in nature. It has been suggested that these habitat may also play an important role in providing shelter during molting, when vulnerability to predation is heightened (Lowery, 1988; Fielder and Thorne, 1990; Smallridge, 1994). These findings showed that the natural habitat is quite important for these kind of creatures. A close relationship exists between stream morphology, substrate and abundance of many crayfish species (Payne, 1984; Foster, 1990; Eversole and Foltz, 1993; Troschel, 1997). Thus, our results are supported by these findings and natural behaviours of crayfish.

According to Streissl and Hödl (2002), substrate preference influenced distribution and habitat differentiation. For example, highest densities of Astacus astacus occurred in gravel and stony areas (Niemi, 1977). Previous studies have clearly stated the relevance of providing suitable habitats for early juveniles during the culturing, also showing the ability of species for displaying clear preferences for some of the types 
of habitats offered (Du Boulay et al., 1993; Karplus et al., 1995; Savolainen et al., 2003; Viau and Rodríguez, 2010; Türkmen and Karadal, 2012b). Stevens and Kittaka (1998) reported that the settlement patterns exhibited by king crab (Paralithodes camtschaticus) were probably a response to the physical characteristics of the substrates, such as the size of particles or interstitial spaces, rather than to organic components.

These findings are emphasized importance of substrate for other crayfish and decapod species and increased quality of the study.

\section{REFERENCES}

Du Boulay, A.J.H., Sayer, M.D.J., Holdich, D.M. 1993. Investigations into intensive culture of the australian red claw crayfish Cherax quadricarinatus. Freshwater Crayfish, 9:70-78.

Eversole, A.G., Foltz, J.W. 1993. Habitat relationships of two crayfish species in a mountain stream. Freshwater Crayfish, 9:300-310.

Fielder, D.R., Thorne, M.J. 1990. Are shelters really necessary? In: Australian fisheries: aquaculture special: redclaw, M. Macreadie (Ed), Australian Government Publishing Service, Canberra, pp. 26-28.

Foster, J. 1990. Factors influencing the distribution and abundance of the crayfish Austropotamobius pallipes in Wales and the Marches, U.K. Freshwater Crayfish, 8:78-98.

Herrnkind, W.F., Butler, M.J. 1986. Factors regulating postlarval settlement and juvenile microhabitat use by spiny lobsters Panulirus argus. Marine Ecology Progress Series, 34:23-30. doi:10.3354/meps034023

Jones, C.M., Ruscoe, I.M. 2001. Assessment of five shelter types in the production of redclaw crayfish Cherax quadricarinatus (Decapoda: Parastacidae) under earthen pond conditions. Journal of the World Aquaculture Society, 32:41-52. doi:10.1111/j.1749-7345.2001.tb00920.x

Karadal, O., 2012. Substrate selection and effects of different substrates on survival and growth of juveniles of the freshwater crayfish Cambarellus patzcuarensis (Villalobos, 1943) (in Turkish with English abstract). M.Sc Thesis. Graduate School of Natural and Applied Sciences, Ege University, Bornova, İzmir. 68 p.

Karplus, I., Barki, A., Levi, T., Hulata, G., Harpaz, S. 1995. Effects of kinship and shelters on growth and survival of juvenile Australian redclaw crayfish (Cherax quadricarinatus). Freshwater Crayfish, 10:494-505.

Kurniasih, T. 2008. The Evaluation on Growth, Survival Rate and Sexua Dimorfisme of Papua (Cherax albertisii) and Australian (Cherax quadricarinatus) Freshwater Crayfish (in Indonesian with English abstract). Jurnal IImu-ilmu Perairan dan Perikanan Indonesia, 15(1):61 68.

Kusmini, I.I. 2009. Phenotype and Genotype Characteristics of Blue Crayfish (Cherax albertisii) and Red Claw (Cherax quadricarinatus) Hybrid (in Indonesian with English abstract). Bogor Agricultural University, Institute of Agriculture, M.Sc. Thesis, $54 \mathrm{p}$.

Lowery, R.S. 1988. Growth, moulting and reproduction. In: Freshwate crayfish - Biology, management and exploitation. D.M. Holdich, R.S. Lowery (Eds), Croom Helm, London, pp. 83-113.

Miller-Morgan, T. 2010. A Brief Overview of the Ornamental Fish Industry and Hobby. In: Fundamentals of Ornamental Fish Health. H.E. Roberts (Ed), Blackwell Publishing, USA, pp. 25-32.
Viau and Rodríguez (2010) indicated that juveniles showed marked preference for pebbles over the other substrates independently of body weight or acclimation to a particular substrate. They noticed that it was feasible that a nutritional or behavioral response to a substrate similar to the one found in nature increased the growth of these juveniles. These findings are also supported by our results.

In conclusion, on the purpose of growing, preference and keeping of juvenile $C$. albertisii in aquarium systems, the present works suggest that the pebbles can be used as a substrate for juvenile blue tiger crayfish.

Molony, B.W., Bird, C. 2005. Are marron, Cherax tenuimanus (Crustacea: Decapoda), populations in irrigation reservoirs habitat limited? A trial using artificial habitats. Lakes \& Reservoirs: Research \& Management, 10:39-50. doi:10.1111/j.1440-1770.2005.00252.x

Niemi, A. 1977. Population studies on the crayfish Astacus astacus (L.) in the river Pyhäjeki, Finland. Freshwater Crayfish, 3:81-94.

Payne, J.F. 1984. Factors influencing patterns of crayfish distribution. Freshwater Crayfish, 7:100-110.

Savolainen, R., Ruohonen, K., Tulonen, J. 2003. Effects of bottom substrate and presence of shelter in experimental tanks on growth and survival of signal crayfish, Pacifastacus leniusculus (Dana) juveniles. Aquaculture Research, 34(4):289-297. doi:10.1046/j.1365-2109.2003.00817.x

Smallridge, M. 1994. Use of shelters in freshwater crayfish farming. Freshwater Farmer, 2(2):10-11.

Stevens, B.G., Kittaka, J. 1998. Postlarval settling behavior, substrate preference, and time to metamorphosis for red king crab Paralithodes camtschaticus. Marine Ecology Progress Series, 167:197-206. doi:10.3354/meps 167197

Streissl, F., Hödl, W. 2002. Habitat and shelter requirements of the stone crayfish, Austropotamobius torrentium Schrank. Hydrobiologia, 477:195199. doi:10.1023/A:1021094309738

Troschel, H.J. 1997. Distribution and ecology of Austropotamobius pallipes in Germany. Bulletin Français de la Pêche et de la Pisciculture, 347:639647. doi: $10.1051 / \mathrm{kmae} / 1997049$

Türkmen, G., Alpbaz, A. 2001. Studies on Aquarium Fish Imported to Turkey and the Results (in Turkish with English abstract). Ege Journal of Fisheries and Aquatic Sciences, 18(3-4):483-493

Türkmen, G., Karadal, O. 2012a. The Survey of the Imported Freshwater Decapod Species via the Ornamental Aquarium Trade in Turkey. Journal of Animal and Veterinary Advances, 11(15):2824-2827. doi:10.3923/javaa.2012.2824.2827

Türkmen, G., Karadal, O. 2012b. Substrate preference on juvenile red swamp crayfish (Procambarus clarkii) (in Turkish with English abstract). Ege Journal of Fisheries and Aquatic Sciences, 29(2):73-76. doi:10.12714/egejfas.2012.29.2.04

Viau, V.E., Rodríguez, E.M. 2010. Substrate selection and effect of different substrates on survival and growth of juveniles of the freshwater crayfish Cherax quadricarinatus (von Martens, 1868) (Decapoda, Parastacidae). Aquaculture International, 18:717-724. doi:10.1007/s10499-009-9292-0

Wingerter, K. 2011. Freshwater Crustaceans, Part Two: Crayfishes \& Crabs. TFH Magazine, May 2011, pp 82-84. 